\title{
Melatonin attenuates cadmium-induced ovulatory dysfunction by suppressing endoplasmic reticulum stress and cell apoptosis
}

Qingling Yang ${ }^{1,2+}$, Jing Zhu ${ }^{1,2+}$, Xiaoyan Luo ${ }^{1,2}$, Fangyuan Li ${ }^{1,2}$, Luping Cong ${ }^{1,2}$, Yujiao Wang ${ }^{1,2}$ and Yingpu Sun ${ }^{1,2^{*}}$

\begin{abstract}
Background: Increasing evidence demonstrate that cadmium (Cd) has adverse effects on the mammalian reproductive system. However, the mechanisms underlying the effects of $\mathrm{Cd}$ on ovarian function and the strategies to reverse these effects have not been fully elucidated.

Methods: In this study, 60 CD-1 mice were divided into four groups (control, melatonin, Cd, Cd with melatonin). During the treatment for 14 days, body weight was measured every 2 days. After the treatment, ovaries were isolated and weighted to observe the morphological and biological characteristics. Statistical analyses were performed using one-way ANOVA followed by Fisher's-multiple range test or chi-squared test, A $P$ value $<0.05$ indicated statistical significance.

Results: We observed that $\mathrm{Cd}$ exposure induced ovulatory dysfunction, demonstrated by the reduced number of ovulated oocytes numbers in the Cd group. However, this endoplasmic reticulum (ER) pathway was activated in the $\mathrm{Cd}$-exposed ovaries and the expression of GRP78, ATF4, CHOP, and p-JNK was upregulated, which was reversed by treatment with melatonin. Furthermore, we found that melatonin inhibited Cd-induced activation of cleaved caspase-3, restored the ratio of Bax/Bcl-2, and ultimately decreased the apoptosis of granular cells as detected by TUNEL staining.

Conclusion: Collectively, our findings reveal that melatonin attenuated $\mathrm{Cd}$-induced ovulation dysfunction and cell apoptosis by inhibiting the activation of the ER pathway. Thus, melatonin can be a potential agent to protect mammalian ovaries against $\mathrm{Cd}$ toxicity.
\end{abstract}

Keywords: Cadmium, Melatonin, Ovulation, Endoplasmic reticulum (ER) pathway

\section{Introduction}

Cadmium $(\mathrm{Cd})$ is a ubiquitous environmental contaminant, which cannot be degraded [1]. Exposure to $\mathrm{Cd}$ in the general population occurs through the consumption of polluted food or water, cigarette smoking and the inhalation of contaminated air [2]. Occupational exposure also occurs usually due to mining, welding, electroplating, and the manufacture of $\mathrm{Cd}$-containing batteries and pigment [3]. Cd accumulates in many tissues including

\footnotetext{
*Correspondence: syp2008@vip.sina.com

${ }^{\dagger}$ Qingling Yang and Jing Zhu contributed equally to this work.

${ }^{1}$ Reproductive Medical Center, First Affiliated Hospital of Zhengzhou

University, Zhengzhou, China

${ }^{2}$ Henan Province Key Laboratory for Reproduction and Genetics, Zhengzhou, China
}

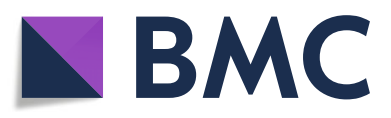

(๑) The Author(s). 2019 Open Access This article is distributed under the terms of the Creative Commons Attribution 4.0 International License (http://creativecommons.org/licenses/by/4.0/), which permits unrestricted use, distribution, and

reproduction in any medium, provided you give appropriate credit to the original author(s) and the source, provide a link to the Creative Commons license, and indicate if changes were made. The Creative Commons Public Domain Dedication waiver (http://creativecommons.org/publicdomain/zero/1.0/) applies to the data made available in this article, unless otherwise stated.

lung, kidney, pancreas, liver, testes, and ovaries, once absorbed $[4,5]$.

Mammalian ovaries contain oocytes at different stages of development, and somatic cells of various types. Ovulation is a periodic event, the number of ovulated oocytes strongly associated with female fertility [6]. Increasing evidence demonstrates the reproductive toxicity of $\mathrm{Cd}$ in female animals and humans. In rodents, exposure to $\mathrm{Cd}$ damaged the structure of the ovary, and caused irregular estrous cycles and abnormal hormone synthesis and follicle development [7, 8]. A recent study also reported the toxicity of $\mathrm{Cd}$ on the reproductive system of female birds demonstrated by the ultra-structural changes in the ovarian cells [9]. Cigarette smoking is considered a major source of $\mathrm{Cd}$ in humans. Women 
who smoke showed the shorter menstrual cycles, lower level of estradiol, higher risk of infertility compared with non-smokers [10]. Previous studies suggest that exposure to $\mathrm{Cd}$ could induce apoptosis by activating the endoplasmic reticulum (ER) pathway [11]. The accumulation of unfolded proteins in the ER leads to ER stress, and triggers the unfolded protein response (UPR) [12, 13]. The elevated ER stress activates cell apoptosis through (I) the pro-apoptotic transcriptional factor C/EBP homologous protein (CHOP); (II) the apoptosis signalregulating kinase1 (ASK1)/c-Jun amino terminal kinase (JNK) cascade, and (III) Bax/Bcl-2 [14, 15]. Furthermore, a study on obese mice demonstrated that ER stress is associated with ovulation disorders and deteriorated oocyte quality [16]. However, it is not known if ER stress response is involved in Cd-induced ovulatory dysfunction.

Melatonin (N-acetyl-5-methoxytryptamine), a hormone secreted mainly by vertebrate pineal gland. Peripheral tissues such as retina, gut, ovary, and placenta can also produce this indoleamine hormone [17-19]. Melatonin modulates oxidative stress [20-22], ER stress [23], inflammation [24], apoptosis [25, 26], and autophagy [27] in different disorders. Recent studies suggest that melatonin is able to attenuate the ischemic brain damage by reversing ER stress [28, 29]. Studied on a mouse model of also demonstrated the protective role of melatonin against the excessive activation of primordial follicles [30, 31]. Melatonin has an antiapoptotic effect not only in somatic cells [32], but also in testicular germ cells [33]. However, little is known about melatonin's effect on the ovulatory function of Cd-treated female mouse.

The aim of this study was to investigate the detail mechanism of Cd-induced ovary dysfunction, and the possible protective effect of melatonin on the ovary. We found that $\mathrm{Cd}$ activated the ER pathway, which ultimately resulted in cell apoptosis in the ovary. These conditions were partly alleviated by melatonin, which suggests the potential clinical application of melatonin in the protection of ovarian function.

\section{Materials and methods}

\section{Animals experiments}

Female CD-1 mice (5-week-old) were purchased from Beijing Vital River Laboratory Animal Technology Co., Ltd. (Beijing, China). All the animals were kept under a temperature- and humidity-controlled condition on a 12- $\mathrm{h}$ light/dark cycle. They were allowed to acclimatize for a week before treatment and had ad libitum access to food and water. All the experiments have received the approval of institutional review board and the First Affiliated Hospital of Zhengzhou University.
Sixty CD-1 female mice were randomly assigned to four groups. The mice were administered intraperitoneal injections of the vehicle or, melatonin $(25 \mathrm{mg} /$ kg; Sigma, St. Louis, Mo, USA), cadmium chloride [8] $\left(\mathrm{CdCl}_{2}, 5 \mathrm{mg} / \mathrm{kg}\right.$; Sigma, St. Louis, Mo, USA) with or without melatonin [30] $(25 \mathrm{mg} / \mathrm{kg})$ daily for 2 weeks respectively. Melatonin stock solutions were dissolved in $100 \%$ ethanol and diluted in saline. The final ethanol concentration in the working solutions did not exceed $0.1 \% . \mathrm{CdCl}_{2}$ was dissolved in saline (5 mg/kg).

\section{Ovary isolation and oocyte collection}

Ovaries were collected, fixed, and embedded in paraffin. Tissues were serially sectioned (5-um thickness) and stained with hematoxylin and eosin. Images were captured with the Nikon Ni-E microscope. To assess the ovulation function, pregnant mare serum gonadotropin (PMSG, 7.5 I.U.) was intraperitoneally injected to stimulate the ovaries of the mice, followed by injection of 7.5 I.U. human chorionic gonadotropin (hCG) after $48 \mathrm{~h}$ to induce super-ovulation. After $12-14 \mathrm{~h}$, the mice were sacrificed and the oviductal ampullae were broken to obtain the cumulus-oocyte complexes (COCs). Subsequently, COCs were pipetted in the in-vitro fertilization (IVF) medium (Vitrolife Sweden AB) containing 5\% human serum albumin (Irvine Scientific) and $0.1 \%$ hyaluronidase (Sigma) to remove the cumulus cells. The number of ovulated oocytes was counted under a stereoscopic microscope (Nikon SMZ800N, Tokyo, Japan).

\section{Western blot analysis}

At least three ovaries were homogenized in the lysis buffer from the protein extraction kit (Sangon Biotech, Shanghai, China). A protein quantitation kit (Bio-Rad) was used to measure the concentrations of the protein solutions. Briefly, the protein samples were separated by $10 \%$ SDS-PAGE gel and transferred onto a PVDF membrane. The membranes were blocked with $5 \%$ defatted milk in Tris-buffered saline containing Tween20 (TBST) for $1 \mathrm{~h}$ at room temperature. Next the proteins were incubated with primary antibodiesGRP78 (1:1000, Cell Signaling Technology, Inc.), ATF4 (1:1000, Cell Signaling Technology, Inc.), CHOP (1:1000, Cell Signaling Technology, Inc.), phosphorJNK (1:1000, Cell Signaling Technology, Inc.), Bax (1: 1000, Proteintech, Inc.), Bcl-2 (1:1000, Proteintech, Inc.), and cleaved caspase 3 (1:1000, Cell Signaling Technology, Inc.), overnight at $4{ }^{\circ} \mathrm{C}$ respectively. AntiGAPDH monoclonal antibody (1:2000, Proteintech, Inc.) was used as a loading control. After incubation with horseradish peroxidase-conjugated secondary 
antibodies for $1 \mathrm{~h}$ at room temperature, the proteins were detected by enhanced chemiluminescence detection system (Bio-Rad).

\section{RNA extraction and real-time polymerase chain reaction (PCR)}

Total RNA was extracted by using the micropurification kit (Qiagen, Dusseldorf, Germany), and the synthesis of cDNA was performed with a reverse transcription kit (Takara, Kusatsu, Japan) according to the manufacturer's protocol. Real-time PCR was performed using the SYBR Green PCR kit (Qiagen, Dusseldorf, Germany) and Quantstudio $12 \mathrm{~K}$ Flex (Applied Biosystems). The primers sequences of GRP78, ATF4, s-XBP1, CHOP, GAPDH are shown in Table 1. Relative gene expression was calculated basing on the $2^{-\Delta \Delta C T}$ method. Each sample was measured in triplicate in each experiment.

\section{Terminal deoxynucleotidyl transferase-mediated dUTP-} biotin nick end labeling (TUNEL) assay

To detect the apoptotic rates of the ovarian sections, In Situ Cell Death Detection Kit (Roche, Penzberg, Germany) was purchased to carry out TUNEL analysis based on the manufacturer's instructions. After incubation in TUNEL reaction mixture for $1 \mathrm{~h}$ at $37^{\circ} \mathrm{C}$, the sections were washed twice and counterstained with Hoechst $33342(10 \mu \mathrm{g} / \mathrm{mL})$ for $10 \mathrm{~min}$ to stain the nuclei. Finally, the sections were mounted on slides and the images were captured under a fluorescence microscope (Nikon Ni-E, Tokyo, Japan).

\section{Statistical analysis}

Data are presented as mean $\pm \mathrm{SD}$. All the data were analyzed by one-way ANOVA followed by Fisher's-multiple range test or chi-squared test, using the SPSS 17.0 Package (SPSS Inc., US). A $p$ value $<0.05$ indicated statistical significance.

\section{Results}

Melatonin reverses the ovulatory dysfunction in cdtreated mice

The body weights of the mice were recorded every other day. After treatment for 14 days, the ovaries of each group were harvested, and weighed with an electronic weighing balance. Relative ovary weight was calculated as a proportion of the final body weight before euthanasia, expressed as $\mathrm{mg} / \mathrm{g}$ body weight. The results showed that the Cd-treated group had significantly less body weight than the control group from the 4th day of the treatment. Melatonin ameliorated the effect of $\mathrm{Cd}$ on body weights (Fig. 1a). However, there were no significant differences in the relative ovary weights between the groups (Fig. 1b).

To determine the effects of $\mathrm{Cd}$ on ovarian function, we observed the ovarian morphological changes in each group. The ovary consists of follicles at different developmental stages. The formation of antral follicles determined the ovulation in individuals. According to a previous study, the antral follicles had independent antral spaces containing follicular fluid, and the antral follicles were defined as atretic if they contained at least 20 apoptotic granular cells, and a degenerating or apoptotic oocyte [34]. After the injection of the Cd-treated mice with ovulatory gonadotropins, the ovarian histology of the mice showed less antral and more atretic follicles compared to other groups (Fig. 1c), which indicated the ovulatory dysfunction in Cd-exposed ovaries. The addition of melatonin could partially attenuate the degeneration of oocytes. To further evaluate the variation of ovulatory function, we measured the number of ovulated oocytes after the stimulation of super-ovulation. As expected, the number of ovulated oocytes in the oviduct was significantly reduced after $\mathrm{Cd}$ treatment, and melatonin considerably restored the impaired oocyte release in the Cd-treated mice (Fig. 1d). These results indicate that intraperitoneal injection of $\mathrm{Cd}$ induces ovulatory dysfunction and melatonin could alleviate the damage.

\section{Melatonin inhibits the ER stress in cd-exposed ovaries} ER stress has been demonstrated to be a key mechanism underlying $\mathrm{Cd}$-induced cell death. To elucidate the molecular mechanisms underlying the alleviation of ovulation disorders in mice by melatonin, we carried out the western blot assay, and the results showed that the expression of the proteins- GRP78 and ATF4 was significantly upregulated in ovaries of $\mathrm{Cd}$-exposed mice.

Table 1 Primer sequences

\begin{tabular}{|c|c|c|}
\hline Gene & Forward & Reverse \\
\hline GRP78 & 5'-GGTGGGCAAACCAAGACATT-3' & 5'-GCCACCACTTCAAAGACACCA-3' \\
\hline ATF4 & 5'-GGAATGGCCGGCTATGG-3' & 5'-TCCCGGAAAAGGCATCCT-3' \\
\hline s-XBP1 & 5'-GGTCTGCTGAGTCCGCAGCA-3' & 5'-AGGCTTGGTGTATACATGG-3' \\
\hline $\mathrm{CHOP}$ & 5'-TGAAGATGAGCGGGTGGC-3' & 5'-TCGTTCCTGGGGATGAGATA-3' \\
\hline GAPDH & 5'-TGGCAAAGTGGAGATTGTTGCC-3' & 5'-AAGATGGTGATGGGCTTCCCG-3' \\
\hline
\end{tabular}




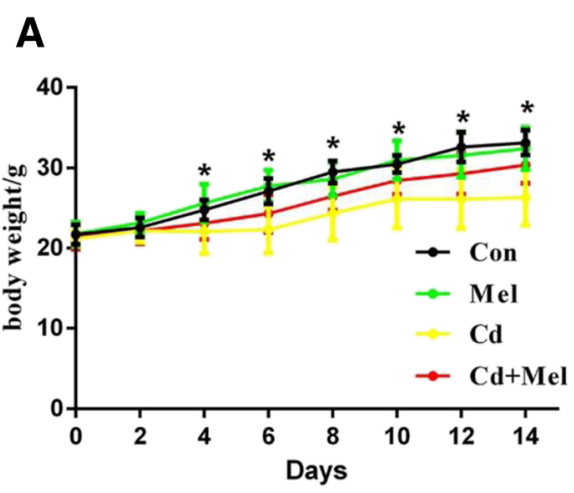

B

C
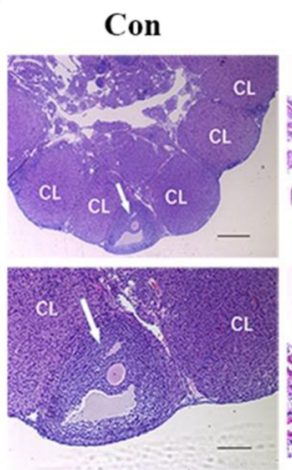

Mel
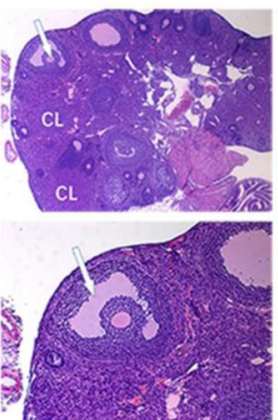

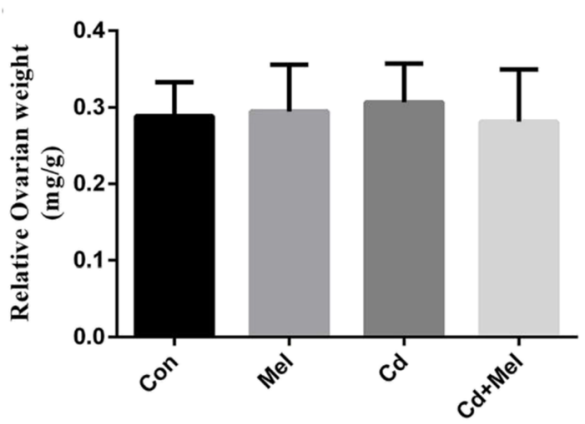

Cd

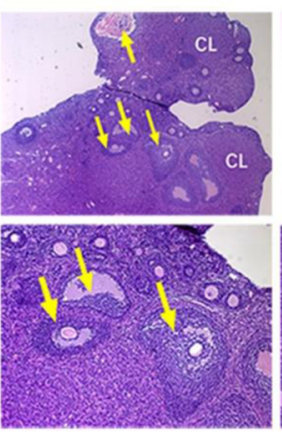

Cd+Mel

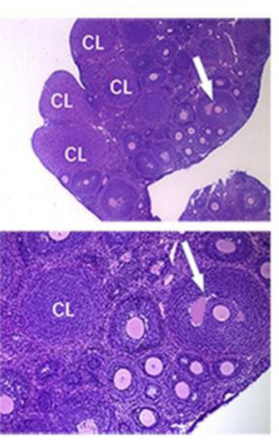

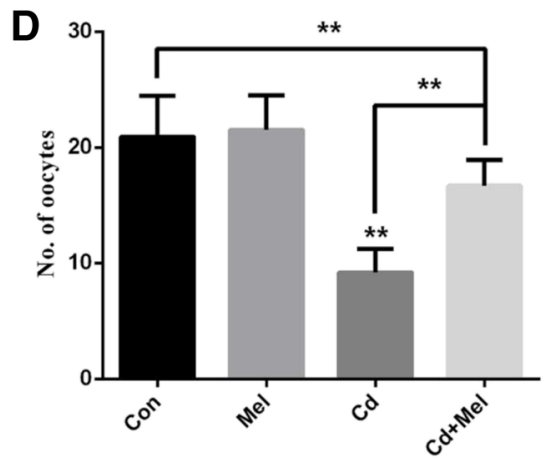

Fig. $1 \mathrm{Cd}$ treatment disrupted physiologic functions of ovary. a Body weight were conducted every other day during $\mathrm{Cd}$ treatment, $\mathrm{Cd}(5 \mathrm{mg} / \mathrm{kg})$ group are significantly lighter than the other groups from the fourth day of treatment. $\mathbf{b}$ Comparison of relative ovary weights between the groups. c Ovarian morphology by H\&E staining. CL, corpus luteum; white arrow, antral follicle; yellow arrow, atretic follicle. The scale bars represent $250 \mu \mathrm{m}$ (upper panel), $100 \mu \mathrm{m}$ (lower panel). d Number of ovulated oocytes obtained from oviduct. Data are presented as means \pm SD. ${ }^{*} P<0.05$ and ${ }^{*} P<0.01$, compared with the controls

However, melatonin notably attenuated the Cd-evoked upregulation of GRP78 and ATF4 (Fig. 2a and b). CHOP, a downstream target of ATF4, was analyzed. The results showed that melatonin significantly inhibited Cd-induced upregulation of CHOP (Fig. 2a and b). Phosphorylated JNK (p-JNK), downstream of sXBP-1 also exhibited the similar variation tendency as CHOP (Fig. 2a and b). We also examined the expression of ER stress-related genes (GRP78, ATF4, spliced XBP-1 transcript, CHOP) in the ovaries of different groups (Fig. 3c). The results revealed that $\mathrm{Cd}$ exposure significantly increased the mRNA levels of GRP78, ATF4, CHOP comparing to the control ovaries, and tended to have higher expression of $s X B P-1$. Notably, administration of melatonin was able to reduce the ER stress in $\mathrm{Cd}$-treated mice comparable to the controls (Fig. 3a). These results suggest that administration of melatonin markedly inhibited ER-stress and its downstream targets, and hence prevented cell apoptosis in the Cd-exposed ovaries. In melatonin-treated group, the ER pathway 

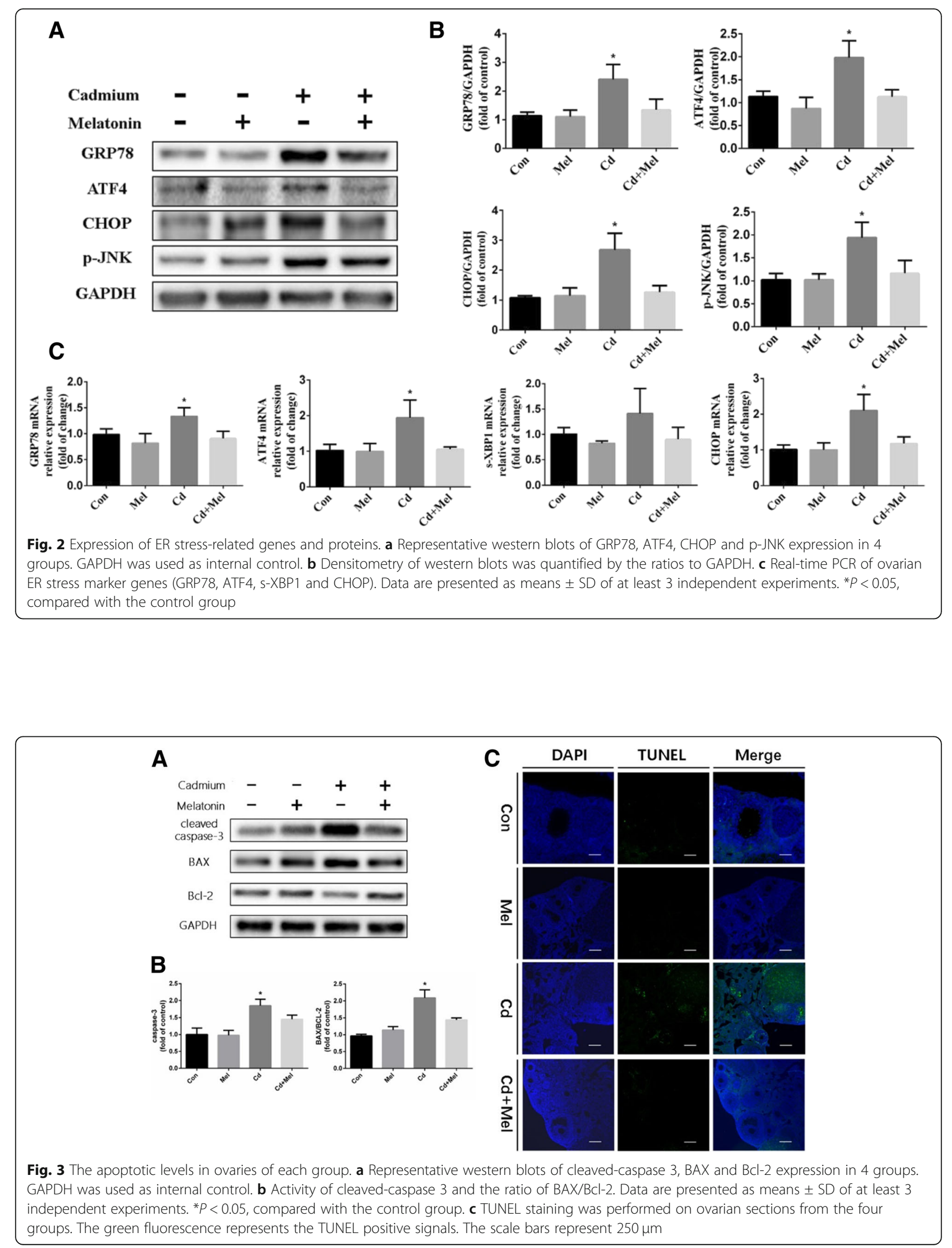
was not be inhibited, we speculate that the oxidation of tissues is at low levels in normal circumstances, therefore, melatonin does not influence the ER pathway when it was given alone.

\section{Melatonin inhibits apoptosis in the ovaries}

Increased ER stress induced cell apoptosis by activating the caspase pathway; hence, we examined the protein expression of cleaved caspase-3, Bax and Bcl-2 in the ovary by western blotting. Results showed that the protein expression of cleaved caspase- 3 indeed substantially increased in $\mathrm{Cd}$-exposed ovaries. Meanwhile, administration of melatonin attenuated the cleaved caspase- 3 level indistinguishable from the controls. The $\mathrm{Cd}$ group showed a higher level of Bax and a lower level of Bcl-2 protein than the control. Melatonin reversed the negative effects of $\mathrm{Cd}$ treatment on the expression of $\mathrm{Bax}$ and $\mathrm{Bcl}-2$ proteins. We assessed the $\mathrm{Bax} / \mathrm{Bcl}-2$ ratio; results showed that the ratio of $\mathrm{Bax} / \mathrm{Bcl}-2$ was considerably higher in the $\mathrm{Cd}$-exposed ovaries than in the ovaried of the mice in the control group. The elevated ratio was reversed by melatonin (Fig. 3a and b). Next, we performed the TUNEL staining to determine apoptosis levels in the ovaries of the mice in the $\mathrm{Cd}$ with and the $\mathrm{Cd}$ without melatonin groups. TUNEL assay exhibited more positive signals after $\mathrm{Cd}$ exposure, and there were more apoptotic granular cells in the developing follicles; the addition of melatonin reduced the number of TUNEL-positive cells in the ovary sections (Fig. 3c), indicating that $\mathrm{Cd}$ induced cell apoptosis which could be attenuated by the administration of melatonin.

\section{Discussion}

$\mathrm{Cd}$ exposure is associated with female infertility and in vitro fertilization outcomes in humans $[35,36]$. In female mice, $\mathrm{Cd}$ induces cell apoptosis, and disrupts the normal estrous cycle and hormone synthesis [7, 8]. Therefore, some antiapoptotic compounds have been investigated to evaluate their protective effects against $\mathrm{Cd}$ induced histologic damage. Such compounds include resveratrol [37], quercetin [8], and melatonin [38, 39]. In addition, our previous studies demonstrated the protective effect of melatonin on oocyte quality and the developmental potential of embryo in mice [22]. In the present study, we showed that melatonin partially reversed $\mathrm{Cd}$-evoked pathohistological damage and increased the number of ovulated oocytes. However, the underlying mechanisms were not well elucidated.

ER is sensitive to the disruption of cellular homeostasis. Perturbed ER function, known as "ER stress", is able to trigger the UPR to restore cellular homeostasis [12, 13]. Earlier studies indicated that Cd-induced cell apoptosis and tissue damage occur through the activation of the ER pathway [33, 40]. In order to establish a link between ER stress and Cd-induced ovulatory dysfunction, we analyzed the expression of related genes and proteins. The mRNA level of sliced XBP-1-an important downstream molecule of the IRE1 pathway, was also increased in the ovaries of $\mathrm{Cd}$-exposed mice. The protein and the mRNA levels of GRP78, ATF4 and CHOP were significantly upregulated, indicating the activation of the PERK pathway. These results were consistent with previous findings that $\mathrm{Cd}$ affects the reproductive system by elevating the level of ER stress in chicken ovary [9]. Another study also revealed that melatonin could reverse hepatic steatosis through the suppression of ER stress [41]. A recent study reported that melatonin prevented $\mathrm{Cd}$-induced testicular germ cell death via the inhibition of ER signaling [33]. All the results of this study and the findings in previous research indicate that melatonin could partially reverse Cd-induced ER stress.

Excessive ER stress is related to cell apoptosis. CHOP and $\mathrm{p}-\mathrm{JNK}$ are proapoptotic proteins that could promote the expression of apoptosis-related proteins [14, 15]. The phosphorylation of JNK inhibits the expression of antiapoptotic Bcl-2 protein and promotes the accumulation of active proapoptotic Bax protein [42]. Our results showed a significant upregulation of cleaved caspase 3 and a significantly increased ratio of $\mathrm{Bax} / \mathrm{Bcl}-2$ in $\mathrm{Cd}$ treated ovary which corroborates the results of previous studies [8]. In addition, the administration of melatonin significantly downregulated the expression of cleaved caspase 3. The upregulation of Bax and downregulation of $\mathrm{Bcl}-2$ were also partially restored by melatonin. Importantly, melatonin significantly reduced the positive signals of TUNEL staining, indicating its antiapoptotic effect.

\section{Conclusion}

Taken together, our study demonstrated that melatonin can ameliorate Cd-induced ovulatory dysfunction and ovarian injury by suppressing ER stress, suggesting that administration of melatonin has a protective effect against ovary damage caused by $\mathrm{Cd}$ exposure. However, additional studies are still needed to investigate the modulatory pathway.

\section{Abbreviations}

Cd: Cadmium; COCs: Cumulus-oocyte complexes; ER: Endoplasmic reticulum; hCG: Human chorionic gonadotrophin; Mel: Melatonin; PMSG: Pregnant mare's serum gonadotrophin

\section{Acknowledgements}

None.

Authors' contributions

QLY conceived, conceptualized and funded the study; JZ conducted the experiments and wrote the original draft.; $\mathrm{XYL}, \mathrm{FYL}$ helped with the experiments and analyzed the data; LPC and YJW helped with the 
experiments; YPS funded, supervised the study, reviewed and edited the article. All authors read and approved the final manuscript.

\section{Funding}

This research was funded by National Science Foundation for Young Scientists of China (grant number 31401274) and National Natural Science Foundation of China (Grant number 31471404).

\section{Availability of data and materials}

The data used and analyzed during this study are available from the corresponding author on reasonable request.

\section{Ethics approval and consent to participate}

Experimental procedures for mice have received the approval of institutional review board and the First Affiliated Hospital of Zhengzhou University.

\section{Consent for publication}

Not applicable.

\section{Competing interests}

The authors declare that they have no competing interests.

Received: 19 April 2019 Accepted: 8 July 2019

Published online: 29 July 2019

\section{References}

1. Thévenod F, Lee WK. Toxicology of cadmium and its damage to mammalian organs. Met lons Life Sci. 2013;11:415-90.

2. Satarug S, Moore MR. Adverse health effects of chronic exposure to lowlevel cadmium in foodstuffs and cigarette smoke. Environ Health Perspect. 2004;112:1099-103.

3. Nawrot TS, Staessen JA, Roels HA, Munters E, Cuypers A, Richart T, Ruttens A, Smeets K, Clijsters H, Vangronsveld J. Cadmium exposure in the population: from health risks to strategies of prevention. Biometals. 2010;23:769-82.

4. Luevano J, Damodaran C. A review of molecular events of cadmiuminduced carcinogenesis. J Environ Pathol Toxicol Oncol. 2014;33:183-94.

5. Satarug S, Garrett SH, Sens MA, Sens DA. Cadmium, environmental exposure, and health outcomes. Environ Health Perspect. 2010;118:182-90.

6. Hansen KR, Thyer AC, Knowlton NS, Buckner JM, Soules MR, Klein NA. A new model of reproductive aging: the decline in ovarian non-growing follicle number from birth to menopause. Hum Reprod. 2008:23:699-708.

7. Samuel JB, Stanley JA, Princess RA, Shanthi P, Sebastian MS. Gestational cadmium exposure-induced Ovotoxicity delays puberty through oxidative stress and impaired steroid hormone levels. J Med Toxicol. 2011;7:195-204.

8. Nna VU, Usman UZ, Ofutet EO, Owu DU. Quercetin exerts preventive, ameliorative and prophylactic effects on cadmium chloride - induced oxidative stress in the uterus and ovaries of female Wistar rats. Food Chem Toxicol. 2017:102:143-55

9. Na W, Zhe X, Liu T, Min Y, Shu L. Ameliorative effects of selenium on cadmium-induced injury in the chicken ovary: mechanisms of oxidative stress and endoplasmic reticulum stress in cadmium-induced apoptosis. Biol Trace Elem Res. 2017;160:340-51.

10. Soares SR, Simon C, ., Remohí J, ., Pellicer A, . Cigarette smoking affects uterine receptiveness. Hum Reprod 2007, 22:543-547.

11. Kitamura M, Hiramatsu N. The oxidative stress: endoplasmic reticulum stress axis in cadmium toxicity. Biometals. 2010;23:941.

12. Sano R, Reed JC. ER stress-induced cell death mechanisms is. Biochim Biophys Acta. 1833;2013:3460-70.

13. Anirikh C, Chen AW, Varner JD. A review of the mammalian unfolded protein response. Biotechnol Bioeng. 2011;108:2777-93.

14. Oyadomari $S_{1} .$, Mori M, . Roles of CHOP/GADD153 in endoplasmic reticulum stress. Cell Death Differ 2004, 11:381.

15. Rasheva VI, Domingos PM. Cellular responses to endoplasmic reticulum stress and apoptosis. Apoptosis. 2009;14:996-1007.

16. Wu LL, Russell DL, Wong SL, Miaoxin C, Te-Sha T, St John JC, Norman RJ, Febbraio MA, John C, Robker RL. Mitochondrial dysfunction in oocytes of obese mothers: transmission to offspring and reversal by pharmacological endoplasmic reticulum stress inhibitors. Development. 2015:142:681-91.

17. Tan DX, Hardeland R, Back K, Manchester LC, Alatorre-Jimenez MA, Reiter RJ. On the significance of an alternate pathway of melatonin synthesis via 5methoxytryptamine: comparisons across species. J Pineal Res. 2016;61:27-40.
18. Reiter RJ, Rosales-Corral SA, Manchester LC, Tan D-X. Peripheral reproductive organ health and melatonin: ready for prime time. Int J Mol Sci. 2013;14:7231-72.

19. Reiter RJ, Tan DX, Tamura H, Cruz MH, Fuentesbroto L. Clinical relevance of melatonin in ovarian and placental physiology: a review. Gynecol Endocrinol. 2014;30:83-9.

20. Reiter RJ, Mayo JC, Tan DX, Sainz RM, Alatorrejimenez M, Qin L. Melatonin as an antioxidant: under promises but over delivers. J Pineal Res. 2016;61:253-78.

21. Reiter RJ, Tan DX, Galano A. Melatonin: exceeding expectations. Physiology. 2014:29:325-33.

22. Yang Q, Dai S, Luo X, Zhu J, Li F, Liu J, Yao G, Sun Y. Melatonin attenuates postovulatory oocyte dysfunction by regulating SIRT1 expression. Reproduction. 2018;1:81-92.

23. Tuñón MJ, Beatriz SM, Irene C, Almudena L, Daniela V, Marcelino Á, Jesús $P$, Javier GG. Melatonin treatment reduces endoplasmic reticulum stress and modulates the unfolded protein response in rabbits with lethal fulminant hepatitis of viral origin. J Pineal Res. 2014;55:221-8.

24. Cao Z, Fang Y, Lu Y, Tan D, Du C, Li Y, Ma Q, Yu J, Chen M, Zhou C. Melatonin alleviates cadmium-induced liver injury by inhibiting the TXNIPNLRP3 inflammasome. J Pineal Res. 2017;62:e12389.

25. Molpeceres V, Mauriz JL, Garcíamediavilla MV, González P, Barrio JP, Gonzálezgallego J. Melatonin is able to reduce the apoptotic liver changes induced by aging via inhibition of the intrinsic pathway of apoptosis. J Gerontol A Biol Sci Med Sci. 2007;62:687.

26. Wang H, Xu DX, Lv JW, Ning H, Wei W. N-acetylcysteine attenuates lipopolysaccharide-induced apoptotic liver damage in D-galactosaminesensitized mice. Acta Pharmacol Sin. 2010;28:1803-9.

27. Beatriz S-M, Irene C, Daniela V, Marcelino Á, Jesús P, Javier G-G, Tó MJ. Melatonin modulates the autophagic response in acute liver failure induced by the rabbit hemorrhagic disease virus. J Pineal Res. 2014:56:313-21.

28. Silvia C, Maria Cristina A, Luca G, Giuseppe B, Fabrizio P, Walter B. Melatonin reduces endoplasmic reticulum stress and preserves sirtuin 1 expression in neuronal cells of newborn rats after hypoxia-ischemia. J Pineal Res. 2015;57:192-9.

29. Carloni S, Favrais G, Saliba E, Albertini MC, Chalon S, Longini M, Gressens P, Buonocore G, Balduini W. Melatonin modulates neonatal brain inflammation through ER stress, autophagy and miR-34a/SIRT1 pathway. J Pineal Res. 2016:61:370-80.

30. Jang H, Lee OH, Lee Y, Yoon H, Chang EM, Park M, Lee JW, Hong K, Kim JO, Kim NK. Melatonin prevents cisplatin-induced primordial follicle loss via suppression of PTEN/AKT/FOXO3a pathway activation in the mouse ovary. J Pineal Res. 2016;60:336-47.

31. Ma M, Chen XY, Li B, Li XT. Melatonin protects premature ovarian insufficiency induced by tripterygium glycosides: role of SIRT1. Am J Transl Res. 2017;9:1580.

32. Seong Soon J, Won Dong K, Woo-Yoon P. Melatonin exerts differential actions on $\mathrm{X}$-ray radiation-induced apoptosis in normal mice splenocytes and Jurkat leukemia cells. J Pineal Res. 2010;47:147-55.

33. Yan-Li J, Hua W, Can M, Xian-Feng Z, Cheng Z, Ying Z, Mei Z, YuanHua C, Xiu-Hong M, De-Xiang X. Melatonin alleviates cadmiuminduced cellular stress and germ cell apoptosis in testes. J Pineal Res. 2011;52:71-9.

34. Luo LL, Huang J, Fu YC, Xu JJ, Qian YS. Effects of tea polyphenols on ovarian development in rats. J Endocrinol Investig. 2008;31:1110.

35. Wright KP, Trimarchi JR, Allsworth J, ., Keefe D, . The effect of female tobacco smoking on IVF outcomes. Hum Reprod 2006, 21:2930-2934.

36. Waylen AL, Metwally M, Jones GL, Wilkinson AJ, Ledger WL. Effects of cigarette smoking upon clinical outcomes of assisted reproduction: a metaanalysis. Hum Reprod Update. 2009;15:31.

37. Chunxiao L, Ruijie Z, Chenxia S, Hai Z, Chong X, Wen L, Wei G, Shile H, Long C. Resveratrol prevents cadmium activation of Erk1/2 and JNK pathways from neuronal cell death via protein phosphatases 2A and 5. J Neurochem. 2015;135:466-78.

38. Sara R, Francisco E, Javier C, Reiter RJ, Juan L, José Q. Inhibition of proliferation and induction of apoptosis by melatonin in human myeloid HL-60 cells. J Pineal Res. 2010:42:131-8.

39. Francesca L, Barbara C, Rosa C, Michela B, Ferdinando M, Stefano P, Giorgio T, Elisabetta F. Melatonin prevents apoptosis induced by UV-B treatment in U937 cell line. J Pineal Res. 2010;40:158-67.

40. Liu W, Xu C, Ran D, Wang Y, Zhao H, Gu J, Liu X, Bian J, Yuan Y, Liu Z. CaMKII mediates cadmium induced apoptosis in rat primary osteoblasts 
through MAPK activation and endoplasmic reticulum stress. Toxicology. 2018; 406-407:70-80

41. Seung-Jae K, Hye Suk K, Jae-Ho L, Jae-Hyung P, Hwa JC, Jae-Hoon B, ByungChul O, Dae-Kyu S, Won-Ki B, Seung-Soon I. Melatonin ameliorates ER stressmediated hepatic steatosis through miR-23a in the liver. Biochem Biophys Res Commun. 2015;458:462-9.

42. Frank T, Wing-Kee L. Cadmium and cellular signaling cascades: interactions between cell death and survival pathways. Arch Toxicol. 2013;87:1743-86.

\section{Publisher's Note}

Springer Nature remains neutral with regard to jurisdictional claims in published maps and institutional affiliations.

Ready to submit your research? Choose BMC and benefit from:

- fast, convenient online submission

- thorough peer review by experienced researchers in your field

- rapid publication on acceptance

- support for research data, including large and complex data types

- gold Open Access which fosters wider collaboration and increased citations

- maximum visibility for your research: over $100 \mathrm{M}$ website views per year

At BMC, research is always in progress.

Learn more biomedcentral.com/submissions 